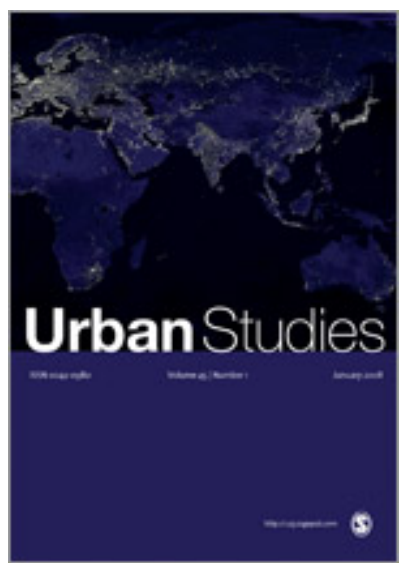

\title{
Four Types of Urban Austerity. Public Land Privatizations in French and Italian Cities
}

\begin{tabular}{|c|c|}
\hline Journal: & Urban Studies \\
\hline Manuscript ID & CUS-740-18-07.R1 \\
\hline Manuscript Type: & Article \\
\hline $\begin{array}{l}<\mathrm{b}>\text { Discipline: Please select a } \\
\text { keyword from the following } \\
\text { list that best describes the } \\
\text { discipline used in your paper.: }\end{array}$ & Planning \\
\hline $\begin{array}{r}\text { World Region: Please select } \\
\text { the region(s) that best reflect } \\
\text { the focus of your paper. } \\
\text { Names of individual countries, } \\
\text { cities \& economic groupings } \\
\text { should appear in the title } \\
\text { where appropriate.: }\end{array}$ & Europe, Western Europe \\
\hline $\begin{array}{r}\text { Major Topic: Please identify } \\
\text { up to } 5 \text { topics that best } \\
\text { identify the subject of your } \\
\text { article.: }\end{array}$ & Land Use, Method, Planning, Policy, Local Government \\
\hline $\begin{array}{r}\text { You may add up to } 2 \text { further } \\
\text { relevant keywords of your } \\
\text { choosing below: }\end{array}$ & Urban Austerity, Intergovernmental System \\
\hline
\end{tabular}

\section{SCHOLARONE Manuscripts}




\title{
Four Types of Urban Austerity. Public Land Privatizations in French and Italian Cities
}

Félix Adisson and Francesca Artioli

\begin{abstract}
This paper contributes to current debates on urban austerity by comparing public land privatizations in French and Italian cities. These privatisations have emerged in several countries during the last two decades as a recurring austerity measure. However, current research does not explain how similar national public land austerity policies result in diverse urban outcomes. This paper tackles this limit by developing an analytical model of the different types of urban austerity. It uses the intergovernmental system and local policy capacity as the main variables to explain four local patterns of austerity, i.e. gridlock austerity, nationally mitigated austerity, locally mitigated austerity, or opportunistic austerity. Drawing on nine case studies covering two public landowners, the paper shows that public land austerity policies have become routine practice based on compromises in French cities, but conflictual and based on ad hoc solutions in Italian cities.
\end{abstract}

\section{Keywords}

Land use, Method, Planning, Policy, Local government, Urban austerity, Intergovernmental system 


\section{Introduction}

It is now clear that austerity is no longer a temporary response to the 2008 financial crisis but a long-term urban policy framework in Western countries. Following Blyth (2013), austerity can be defined as a rhetorical and a practical attempt to make the state responsible for the economic crisis. It is based on the idea that economic recovery depends on state ability to restore the so-called 'confidence' of the financial markets, especially the sovereign debt market Austerity's main features are the reduction of public debt and deficits by cutting public expenditure, as well as reorganising and privatising public assets, companies, services and employment at all levels of government, including the local one (Pike et al. 2018, p.4). These austerity measures have concentrated effects on urban spaces and populations and their analysis has opened a particular research agenda on urban austerity (Peck 2012; Meegan et al. 2014).

This paper contributes to current debates on urban austerity by investigating its varieties through the study of public land ${ }^{1}$ privatizations and their consequences for urban spaces in Europe. This focus on land privatizations is based on the following premises: (i) the centrality of land ownership in urban processes, especially urban development; (ii) the crucial role of state organisations in contemporary urban land dynamics both as regulators and land providers; and (iii) the sale of public real estate as a recurring measure of the austerity toolbox.

Public land austerity policies consist of reorganising and selling public lands and buildings, with the aim of cutting real estate management costs and boosting land disposal revenue. While these processes are at work in countries as different as France, Italy, the UK, Finland and Canada (Artioli 2016; Adisson 2018; Christophers 2017; Hyötyläinen

\footnotetext{
${ }^{1}$ The term 'public land' encompasses the land owned by municipalities which is not addressed in this paper. As for state property, the privatization of municipal lands in Europe is also driven by austerity, but can differ in terms of approach, actors, and regulations (on the distinction between state and municipal land, see Haila 2016: 20).
} 
and Haila 2017; Eidelman 2016), both the privatization processes and outcomes differ between these countries and their cities. In some cases, they only involve rent maximising strategies. In other cases, newly-developed privatized land projects include redistributional goals. This paper explores how similar national public land policies framed by the same policy paradigm of austerity nonetheless result in diverse urban outcomes.

Existing urban austerity research literature provides limited theoretical explanations for such differences which are seen as the result of different socio-economic conditions or simply overlooked by single case studies. This paper seeks to redress these limitations in two related ways. Firstly, it provides an analytical urban austerity model based on political and organisational variables that explain four local types, i.e. gridlock austerity, nationally mitigated austerity, locally mitigated austerity, or opportunistic austerity. These patterns depend on how the intergovernmental system and local policy capacities affect public land austerity policy. Secondly, at an empirical level, the paper provides a multi-level and international comparison based on research into the sale and redevelopment of public land in nine French and Italian cities. This medium-N and qualitative comparative method highlights the different timeframes, processes and material outcomes that can characterize public land austerity locally. The paper demonstrates that public land austerity policies have become routine practice based on compromises in French cities, but conflictual and depending on ad hoc solutions in Italian cities. It shows that public land austerity constitutes a state-led process of ownership reform and privatisation that restructures the tenure and layout of the built environment in ways that are shaped by both redistributional policies and local policy capacity.

We first discuss the limitations of previous urban austerity literature in explaining different outcomes between countries and cities, and present the comparative analytical model developed to overcome these limits. Secondly, we explain the benefits of using the model in the case of public land reforms in France and Italy. Thirdly, we compare these public land austerity policies, stressing similarities in reforms but differences in development outcomes in the cities of these countries. Lastly, we analyse the roles that 
the intergovernmental system and local policy capacity play in this differentiation before discussing how this results in different trajectories in terms of local adaptations to the policy paradigm of austerity.

\section{Gridlock, mitigated, opportunistic: different types of public land austerity in cities}

Understanding austerity requires an awareness of its geographical diversity and specific local and national factors that underpin differences. When analysing diversity, existing literature displays the limitations typical of an emerging research field: a focus on single case studies (based on a city, country, or policy sector) and a lack of comparison that makes it difficult to explain the variety of austerity policy processes and outcomes. Furthermore, when this process is analysed as a local government response to budget difficulties, there is often a focus on extreme cases such as Detroit (Peck and Whiteside 2016) or Athens (Chorianopoulos and Tselepi 2017). Like a magnifying glass, these extreme cases are good at highlighting the characteristics of a phenomenon (Gerring 2007: 101-2) but have limited representativeness if they are not compared to a larger urban sample.

When diversity is analysed, authors consider that localities are not impacted in the same way because of their different socio-economic features (Meegan et al. 2014; Monastiriotis 2011) or fiscal basis (Gray and Barford 2018). However, moving away from simply focusing on these features, we contend that institutional and political variables shape the processes and outcomes of public land austerity policies. Davies and Blanco (2017) have taken a first step in this direction: when comparing six cities in Spain and the UK, they stressed that the 'institutional forcefields' constituted by cities and regions, as well as 'local traditions mediated the politics and temporalities of austerity' (p.1530). However, their comparison relies on an empirical analysis of local politics and does not define which variables actually account for differentiation or how they do so. In response, this paper draws upon traditional institutional factors highlighted in comparative political research and considers that the intergovernmental system and local policy capacities mediate austerity measures. From there, it develops a systematic comparative framework of the types of urban austerity. 
The first factor is the intergovernmental system. In urban austerity literature, austerity is 'offloaded' to the local level which has limited or no room for manoeuver (see Peck 2012 on the U.S. case). In a nutshell, 'Washington does to the states, the states do to cities and cities do to low-income neighbourhoods' (p.632). This offloaded austerity is one way in which the intergovernmental system structures the implementation of austerity policies. However, we propose a more complete view of the intergovernmental system, meaning the set of institutional and political ties between central and local government. First, the literature on territorial politics and multilevel governance has underlined the complex patterns of political negotiations between different levels of governments (i.e., Keating 2013). Central government rules are negotiated and adjusted at local level (Goldsmith and Page 2010). It is then likely that these political and institutional ties also function as bargaining arenas in the case of urban austerity measures. Second, in European states, the intergovernmental system has a strong redistributional function in several ways. The transfer of resources from central to local level is one way in which political support for central government is maintained (Tarrow 1977) and inter-regional transfers of income still represent a substantial portion of state budgets (Storper 2016). The welfare state functions through national redistributive mechanisms (income redistribution, pensions, benefits, etc.) that shape both European urban societies and built environment. Therefore, while central authorities may adopt stringent austerity policies, the intergovernmental system can 'soften' austerity at the local level because of these bargaining and distributional features. It can provide local planning authorities with additional resources that help to counteract the power of private market actors (Kantor, Savitch and Haddock 1997) and/or support redistribution programmes (e.g. social housing, green spaces, cultural and health facilities, etc.).

The second factor under consideration is local policy capacity defined as the power of local governments to formulate and implement their own policy agendas. Following decades of research, we consider that this capacity is determined by two main features: power over and power to (Stoker 1995). The former is largely determined by the resources (especially financial resources) at the disposal of local authorities. The latter refers to the 
forms of routinized cooperation between actors belonging to various institutions and interests groups that drive local policies, notably urban development. Therefore, local policy capacity can also reshape austerity policies at local level. Indeed, as certain authors insist, uneven local administrative and financial capacity (Lobao and Adua 2011; Meegan et al. 2014), as well as enduring forms of coordination and redistribution (Davies and Blanco 2017) account for local and regional variation in austerity policies. While the intergovernmental system can contribute to shaping local capacity, the latter has its own autonomy and cannot be considered as simply dependent on supra-local conditions. Indeed, a quick analysis of local capacity within a given country reveals considerable variety, which is the result of long-term institutionalised arrangements, organisations and expertise as well as localized resources and different fiscal bases.

Based on these two factors, we have developed a typology that systemizes four types of urban austerity (see Figure 1). The first axis refers to the degree of redistribution in the intergovernmental system, and the second to local policy capacity in both financial and organisational terms. The two axes are separated for analytical purposes in order to point up their interplay through typology and at the empirical level. Firstly, gridlock austerity is characterized by cuts in government expenditure that are exacerbated by scarce local resources (bottom-left). Secondly, locally mitigated austerity arises from local policy capacity that counterbalances national austerity measures (bottom-right). Thirdly, nationally mitigated austerity results from the persistence of a redistributional intergovernmental system in a context of national austerity reforms and low local policy capacities (top-left). Lastly, situations of opportunistic austerity arise when intergovernmental redistribution combines with high local policy capacity, i.e. where local governments can curb national austerity policies in ways that are favourable to their agendas (top-right).

[Insert Figure 1 here]

\section{Comparing public land austerity policies in French and Italian cities}


We use the comparative model to analyse public land disposals, a typical austerity measure (Peck 2012; Lobao and Adua 2011). Public land austerity policies may be defined as reforms designed to reduce public real estate management and maintenance costs and generate financial gains from sales which have become an increasingly relevant stream of revenues for both debt repayment and new investment. Like many other austerity policies (Streeck 2014), public land austerity policies mainly pit creditors and investors against citizens (Piganiol 2017) and tend to favour the formers. Public administrations sell off their assets and justify doing so by the need to obtain revenues in the face of reduced budget capacities. This relationship between austerity and the sale of public property started long before the 2008 crisis (Kivell and McKay 1988: 174) but the latter reinforced the phenomenon, turning public properties into 'strategic resources' for governments (Besussi 2013).

Public land austerity policies are part of deeper processes of neoliberal state reforms (Christophers 2017; Whiteside 2017). Shaped by new public management principles (Hood 1998) and justified in the name of public debt reduction, these policies fundamentally change how public property is understood and managed - and sometimes redeveloped - by public authorities. They overhaul the legislative framework and apply a whole range of market-based instruments, organisations and calculus for managing public sector land. Accordingly, the central, sectorial and local administrations in charge of public property are either recast or reformed, and became key actors in disseminating these new approaches across various government bodies (Artioli 2016; Adisson 2018). Furthermore, public land austerity policies entail major social and political consequences due to the organisational, redistributional, and welfare functions of public land ownership. This is especially true in European cities where public ownership is historically strong, widespread and politically legitimate (Haussermann and Haila 2004). Public land together with spatial planning policies were used in urban development to channel and regulate market forces and to attain redistributional goals. More generally, this is the means through which public bodies performed their primary tasks and provided part of the benefits of the welfare state (housing, hospitals, etc). 
To analyse how the intergovernmental system and local policy capacity shape different public land austerity policies in cities, we developed a multi-level research design comparing property redevelopment in two sectors (railways and defence), in nine cities located in two different countries (France and Italy). Using a case-oriented comparative approach, similarity and difference are the logical bases used to explain given cases, considered as complex combinations (Della Porta and Keating 2008). Such an approach facilitates generalisations concerning historical divergence, as well as different processes and structures over time. Here, comparing different cities in the same country makes it possible to analyse changes in local policy capacity while cross-country comparisons factor in the effects of the intergovernmental system. The two selected countries - France and Italy - are 'most-similar cases' which make it possible to focus on how the key factors in public land austerity policies actually work. In fact, despite Italian regionalisation, they are similar in terms of their 'Napoleonic' local political administrative systems (Goldsmith and Page 2010) and their urban planning systems and professional cultures (urbanistica and urbanisme) (Directorate General for Regional and Urban Policy 1997). The nine areas are selected through non-random, criterion-based sampling for comparative qualitative research. The main selection criterion is that all cities have a significant military and railway infrastructure. Stemming from this common denominator, we selected a 'maximum variation sample', where the central phenomenon, i.e., state land privatisation and redevelopment, cuts across a variety of cases (Ritchie et al. 2003). This controls for specific local features at country level. Indeed, the nine urban areas (four in France and five in Italy) cover very different city profiles in terms of size, administrative position and capacity, economic position, and real estate market (see Table 1).

Two types of major public landowners are considered in the paper: railway companies and the defence forces. They are among the most important landowners in both Italy and France. In France, railways companies own 110,000 hectares of land and 12.5 million square meters of buildings, while the Ministry of Defense owns 329,431 hectares $(2010)^{2}$.

\footnotetext{
${ }^{2}$ Aggregated data on railway and defense real estate is not available for Italy.
} 
Most importantly, they are major landowners in cities, with properties generally located in peri-central areas. For instance, in the 1980s, before the wave of major urban redevelopment projects on former railway sites, the publicly-owned railway company SNCF possessed no less than 500 hectares in Paris, $4.7 \%$ of the city's total surface area. Similarly, today in Milan, the military and railway areas considered for redevelopment projects represent about 176 hectares (nearly 1\% of the municipal surface area). Consequently, they can provide a significant understanding of state land austerity policies and the consideration of these two sectors within each country controls for sector-specific features and processes.

\section{[Insert Table 1 here]}

We studied public land austerity policies in cities by analysing the scope, procedures, and material outcomes of the sale and redevelopment of military and railways zones since the first initiatives of the late 1990s up to the present. Regarding our key factors for explaining variation, we analysed the intergovernmental system by considering the formal and informal institutions for central and local government bargaining (e.g. the Prefect, political ties of the local elite) and other state policies that apply to land (e.g., housing policy). In order to gauge local urban development policy capacity, we considered both the financial situation of the municipal government and its organisational resources in the field of spatial planning.

Data for this paper comes from multi-location, extensive fieldwork conducted mainly between 2012 and 2014 for the authors' PhD thesis. The main methodology was qualitative and relied on semi-structured interviews in cities, rounded out by interviews at the state level. In total, the paper draws on 273 interviews conducted with railway company and army representatives in charge of real estate, elected local officials and civil servants and officials in other local planning bodies, leaders of local civic groups and activists, and senior officers in charge of national property. In addition, we drew upon analyses of documents related to various redevelopment projects, planning documents, real estate strategies and legal and budgetary regulations for public landowners. 


\section{Similar public property ownership reforms but different development outcomes}

State land austerity policies in the two countries present strong similarities in terms of the drivers of reforms, rationale and organisational choices. In both France and Italy, these policies date from the beginning of the 1990s - long before the 2008 crisis - as a mix of cross-cutting state reforms aimed at 'rationalising' and privatising public land, and sectoral reforms in both the defence and railways fields ${ }^{3}$. They were driven by pressure from central governments to clean up the financial situation of the key defence and railways sectors (and of the public sector in general) by extracting capital gains from privatisations. The underlying legitimising narrative was debt-reduction, in the name of which public real estate was increasingly being analysed in both countries in terms of its management costs and as a potential financial resource.

Ministries of Defence initiated policies to sell off their assets beginning in the early 1990s due to changes in defence strategy at the end of the Cold War and increasing pressure from central government. In France, the Treasury wanted real estate privatisations to balance the defence budget and compensate for the decline in the amounts being allocated from central government. As an extra incentive, revenues raised were reallocated to the defence budget. In Italy, it was the national debt that drove public real estate policy, which then targeted Defence as one of its major potential sources of income.

Driven by EU market integration, railway sector reforms that started in the 1990s increased pressure on debt-ridden publicly-owned firms with the aim of transforming them into financially sound companies. In both countries, this ultimately culminated in real estate disposal strategies. In France, between 1997 and 2014, a newly-created company in charge of managing the infrastructure was left with two thirds of the public rail debt by the historical operator. In order to balance the books, it was also left with the assets (infrastructure, land, etc.) and, because of this accounting link, reducing the debt

\footnotetext{
${ }^{3}$ For a more detailed demonstration of the arguments presented in this section, see Adisson (2015) and Artioli (2014).
} 
was tied to the sale of assets. The same link between liabilities and assets has existed in Italy since the 1990s - albeit through a different holding company-type arrangement leading to repeated 'spin-off operations' through ad-hoc companies.

To achieve privatisation goals, the organisational and commercial management of state land also evolved. New units in charge of real estate portfolio 'rationalisation' were created within the Ministries of Defence and by the railway operators - the latter also hired managers with backgrounds in planning and real estate. Furthermore, this state land was subject to comprehensive inventories based on categories taken from the private real estate sector to make it more conducive to privatisation.

Despite this similarity in public landownership reforms, the analysis of public land sales and redevelopment in the nine cities reveals sharply differing outcomes between the two countries: privatisation with redistribution in French cities, and gridlock without redistribution in Italian cities. Table 2 summarizes these differences in the effectiveness of privatisation, the procedures used, and the development content.

[Insert Table 2 here]

First, privatisations were much more effective in France. Public lands were sold and redeveloped almost systematically in the four cities and sales concerned both military and railway brownfield sites. As with any kind of regeneration process, implementation is quite long (15 years is a regular timeframe) but once these lands were declared as being no longer useful for their landowners, reflections about redevelopment tended to begin and complete (e.g. the Clichy Batignolles project in Paris, Boulevard de Trêves in Metz). By contrast, in Italy the pace of sale and redevelopment of large publicly-owned properties was much slower and more erratic (for a similar observation see Gastaldi and Camerin 2017). Unlike in France, no material transformations whatsoever took place in any of the five cases considered despite more than a decade of negotiations - and sometimes land transfers - except for one small building in Udine. 
Secondly, while sale and redevelopment processes in France were relatively homogenous and pacified, they tended to be variegated and conflictual in Italy. In France, sale and redevelopment followed procedures and project management processes that were quite 'routinized' and homogeneous from one city to the next. Indeed redevelopment projects in Paris, Nantes, Metz, and Toulon were: i) negotiated by a similar set of actors - the municipality (or metropolitan government), the landowner (the Army or the railway company), the Prefect and other decentralised state offices; ii) relied on a similar set of planning and operational documents (State-Region planning contracts, memoranda of understanding, mixed-development zones, etc.); iii) and managed during the implementation phase by publicly-owned and locally controlled development companies. In Italy, not only did the levels of governments involved as well as their role vary, but their involvement also changed during the negotiation process. Actors' configurations varied greatly over time and from city to city. For instance, in Milan, the role of the Region has depended on the degree of political divergence or alignment with the municipality: it was absent in the early meetings leading to the first agreement, but subsequently played a significant role in the negotiation (albeit limited to the issue of the regional rail transport) through the late 2000s, before being ultimately marginalized. In Bolzano, the provincial government launched the negotiations and technical studies at the end of the 1990s but was then supplanted by a proactive municipality, before eventually taking back control.

Ultimately, the features of urban redevelopments also differed between the two countries. Interestingly, while public land privatisation was on a larger scale in France, the material outcomes tended to be more redistributional and to incorporate more social benefits. Indeed, the end-developments combined similar proportions of market uses (either commercial, residential or office space), public facilities and social housing: several projects include a substantial portion of social housing (ranging from $30 \%$ in Nantes to $50 \%$ in Paris/Clichy Batignolles) and other public amenities (e.g. the New Hôpital de Mercy in Metz or the big public parks in Paris and Nantes). By contrast, the planned material outcomes were more variegated in Italy and tended to be less redistributional. Mixed-use plans were put forward but the shares of social housing, green areas or other 
public facilities differed more between cities and were not achieved. The paper now turns to explaining these differences between France and Italy.

\section{Intergovernmental systems and local capacity to shape public land austerity policy}

\section{The intergovernmental system}

The intergovernmental system - one of the two key explanatory factors considered shapes local implementation of public land austerity policies in two ways: by promoting land uses that provide public facilities and redistributional initiatives such as social housing or cultural and health facilities, and by providing bargaining arenas where austerity can be negotiated. These bargaining and distributional features curb national reforms at local level. Observed differences in intergovernmental systems place the French cities in the upper quadrants of the typology (i.e., nationally mediated austerity and opportunistic austerity), while Italian cities are in the lower quadrants (i.e., gridlock and locally mitigated austerity) (see Figure 1).

In France, two mechanisms provided intergovernmental support for redistributive measures and had a significant impact on both the mitigation and routinization of public land austerity policies. This resulted in the incorporation of redistributional goals into public land redevelopment programmes that were at odds with the dominant revenueraising goal. First, national housing policy supported the sale of a number of public plots at below-market prices and imposed a minimum share of social housing. Since 2005, several laws and decrees have promoted the construction of new homes on public land (laws n. 2005-32 and n. 2013-61). As major landowners, both railway companies and the army were subject to this policy in all cities apart from Metz. More generally, the law on solidarity and urban renewal (Solidarité et Renouvellement urbain) requires local governments to build at least $20 \%$ of social housing within the municipal housing stock. Consequently, public land redevelopment is used by local governments to build social housing in order to achieve this rate. Second, while the Ministry of Defence oversees a reduction in its real estate portfolio, it also supports reconversion programmes for local communities affected by the closure of military bases (Artioli 2016). As stated in a ministerial booklet about reconversion: 'The Ministry of Defence is willing to dispose of 
real estate through a partnership with local governments, by listening to their reconversion projects and facilitating their efforts for reconversion' (Ministère de la Défense, 2006: 11). Since the beginning of the 1990s, this has played a mitigating role: the Ministry has provided local governments with funds for property redevelopment studies and in 2008 it also listed specific assets located in the areas most affected by base closures to be sold for a symbolic amount of one euro (e.g. Metz). In addition to these initiatives, the systematic involvement of others state organisations made the privatization process in France both more homogenous and routinized. Within the Treasury, the department managing state-owned real estate defended the interests of the state as a 'normal' (i.e. private) landowner through carefully overseeing land evaluation processes and approving final sale values. Finally, the Prefects (i.e., the government's representative at local level) both mediated between local governments and landowners and oversaw the integration of national priorities into local redevelopment programmes. In Nantes for instance, the Deputy Director of the Prefect's office in charge of territorial development summed up its role as follows: 'We are needed because the role of central government is to move things forward, mediate and regulate all of these operations' (Interview, September 2012).

Conversely, this intergovernmental involvement is not to be found in Italy. First, available public land was not used to support redistributional policies. Indeed in Italy the production of affordable housing is completely 'decoupled' from public land redevelopment. Apart from a short-lived initiative at the beginning of the 2000 s, the sale and redevelopment of public real estate was not used as a tool to support regional development. The military property reconversion programme did not include any brownfield management tools. Its focus was on defence industries and the professional reconversion of workers. Second, the absence of cross-cutting government planning departments explains the huge range of stakeholders' configurations and procedures at local level. The railway companies and Defence Ministry were standalone actors in sale and redevelopment negotiations with weak institutional ties to local governments, resulting in very erratic communications. Apart from the property owner, the redevelopment process did not involve any other central government department in a 
systematic way. In addition, unlike France, the Italian decentralised state does not have a planning branch involved in negotiating the redevelopment of state land. Finally, despite substantial planning and development legislative and executive powers (Brunazzo 2010), regional governments were not involved in the mitigation or bargaining of public land austerity policies. The uncertain role of the Lombardy Region has been already mentioned. In Udine, the region explicitly avoided any involvement in the planning process. As a regional senior civil servant explained, 'when we transferred [the barracks] to the municipalities, we were very clear about our position, which was 'this is your property now. The Region does not have any resources so everything is up to you.' (Interview, January 2013) In this context of offloaded austerity, only fitful intergovernmental support was provided in Italy. On an ad hoc basis, specific government programmes offered the opportunity to get extra resources to local level for public land redevelopment. For instance, the municipalities of Bolzano and Udine secured a grant from the Department of Infrastructure to set up public-private development companies which never actually got off the ground but still reinforced municipal capacity and legitimacy. This raises the issue of the local policy capacity analysed in the next section.

\section{Local policy capacity: why land privatizations depend more on public resources than on real estate markets}

Operationalization of local policy capacity for land redevelopment is contingent on planning powers which shape public land austerity in two ways: first public land redevelopment depends on planning permission and compliance with planning rules which are the responsibility of local government; second, local planning authorities can decide to buy public property and/or spend money on it with the goal of delivering public amenities (e.g. green spaces). Therefore, both local government capacity to steer urban development (through planning organisation and instruments) and its financial strength affect how and for which purposes public lands are privatized and redeveloped. In our sample, this local planning capacity varies within and between countries. When planning capacity is low, cities experience either nationally mitigated (Toulon, Metz) or gridlock austerity (Taranto, Rome). When it is high, cases range between opportunistically grasped 
by local governments (Nantes, Paris) and locally mitigated austerity (Milan, Bolzano, Udine).

In general, the planning capacity of French cities is high and relies on homogenous organisational arrangements that allow them to play a much more interventionist role in state property privatisation. Combined with the national policies described above, this helps account for the more homogenous and redistributional focus of developments. First, over the last two decades, local governments have invested significantly in public land redevelopment. Transfers from central to local government (dotation globale de fonctionnement) stopped increasing in 2009 and have been decreasing since 2014 . Similarly, local investments grew and then remained stable for thirty years until 2014 when they started to decline (-8\% p.a.). In other words, public land austerity policies were not coupled with local budget austerity until the mid-2010s. More specifically - and this is a key difference with Italy - these public funds were used for spatial planning and development: local governments bought, remediated and redeveloped land before reselling it to real estate developers. A former manager of the municipal development company in charge of the Clichy Batignolles redevelopment project in Paris explains: 'anyway, it costs the municipality money. [...] But, if we adopt a purely economic mindset and consider that 'in any case, any spending must be balanced', we would not carry out this kind of redevelopment' (Interview, April 2012). French municipalities have thus taken charge of the redevelopment of state properties, considering it to be part of their responsibility.

Secondly, French local planning authorities have longstanding expertise in urban development. In all cases, railway and military sites have been redeveloped by (semi)public French development companies that liaised between the public landowner and the real estate developers. These companies are economically and politically controlled by local governments (i.e., municipalities or metropolitan bodies) and almost all of them receive local subsidies to help balance their budgets (development income must balance development costs). However, this local intervention capacity also varies significantly between cities. Annual investment from the City of Paris is 70 times greater than Metz, 
36 times Toulon and 28 times Nantes (disproportionally higher, even after considering size differences). Organisational strength also varies. During the last three decades, the city of Nantes (and its agglomeration) has been able to deliver quality projects autonomously (Pinson 2009) earning it praise as a 'successful model' both nationally and in international networks. By contrast, the city of Toulon, characterised historically by its dependence on publicly-owned military infrastructure, has displayed limited urban development capacity (Artioli 2013).

Italian local governments have lower financial and organisational resources for redeveloping public real estate than their French counterparts. Combined with intergovernmental offloading, their limited investment capacity and greater reliance on market actors in development helps account for the failures and uncertainties of public property privatization and redevelopment in Italy as well as the preference for profitdriven developments. First, in Italy the contraction of local investment started a decade earlier than in France: local fiscal austerity did not allow local governments to mitigate national public land austerity policies. Between 2004 and 2014, municipal investment fell by $110 \% 4$. In a context of structurally limited local government fiscal autonomy, this hampered their ability to invest in public property redevelopment. Furthermore, in the context of a loose and non-redistributional national public property redevelopment framework, there are sharp differences between local governments. The cities of Taranto and Rome have had to contend with debt crises that led central government to appoint special commissioners to take charge of the local finances during the 2000s. The municipality of Taranto has produced public land redevelopment expertise only rarely and intermittently (linked to the specific goals and connections of the deputy-mayors in charge of planning). Conversely, without actually investing, the municipality of Milan has been quite active since 2016 in developing expertise, strategic documents and in organising public consultations to frame future developments.

\footnotetext{
${ }^{4}$ Result based on the data of Istat, Serie storiche, finanza degli enti locali, URL: http://seriestoriche.istat.it/fileadmin/documenti/Tavola_22.14.xls (accessed 9 October 2017).
} 
Second, the Italian planning system is organised around a much less interventionist role for the public sector and a stronger dependence on market actors who are expected to intervene in development at a very early stage and to handle financial and organisational matters. French-style local intermediation between public land ownership and the open market does not exist. In fact, Italian local governments have the opposite goal: to balance their budgets, they need resources and must negotiate the construction of public facilities with private developers based on development fees. Furthermore, this division of labour where the private sector is expected to drive public real estate privatisations has made the latter more dependent on the real estate market. Given the decade-long Italian real estate crisis, the large scale and uncertainties of redevelopment projects, private actors have been reluctant to engage with the process. As a politician in charge of Ministry of Defence issues in Udine argues: 'If the crisis was not there... because it is not enough to change the zoning, it is also necessary to have the money to deal with it and today neither the public nor the private sector have the money' (Interview, January 2012). This was the case even with the most attractive Italian real estate investments in Rome and Milan.

Real estate and land markets are indeed the main factors through which the socioeconomic context influences public land austerity policies. But empirically, our study revealed that they are not a primary factor in explaining either the processes or the content of public land sales and redevelopment. To control for this, our sample included, for each country, cities with very different real estate markets. However, sales and redevelopments were initiated more systematically and extensively in France than in Italy regardless of subnational real estate market variations. Counterfactually, if tight real estate markets directly influenced the launch of redevelopment projects, this would have happened in the attractive cities of Milan or Rome which was not the case. However, these markets constitute a secondary factor as they set the pace of land redevelopment projects. Indeed, the Paris example of Clichy Batignolles is the only redevelopment project from our sample that has been completed. Once the land was serviced by the municipality, real estate developers for the purchase of plots of land were easily found. Conversely, despite the local and intergovernmental resources mobilised in Metz, the depressed market 
conditions clearly slowed down the redevelopment project. In other words, the early stages of land privatization depend more on public resources than on real estate markets.

\section{Varieties of austerity policies: compromise and routine in France, conflict and self- organization in Italy}

The specific local policy capacity and intergovernmental system configuration highlighted by the comparative model delineates two trajectories of local adaptation to public land austerity policies in France and Italy. In France, public land austerity was mitigated and land often seized in an opportunistic manner by local governments to deliver their policy agendas. Intergovernmental support played a crucial role in framing negotiations between the public landowner and the local planning authority. It also included redistributional development programmes that reversed the dominant debtdriven policy and produced affordable housing and/or other public facilities. In many cases, the financial and planning resources of local authorities allowed them to intervene directly in public land redevelopment. Despite differences in the level of resources available to them, they were still operating in a relatively supportive intergovernmental system.

It can be argued that this negotiated and mitigated public land austerity functioned as a compromise between the conflicting goals, tools and constituencies of public debt policies that oppose investors and creditors and citizens' social rights (for a similar argument, see Piganiol 2017). While this may seem paradoxical, one result is that several local governments have taken advantage of privatisations to steer public land redevelopment in politically rewarding directions (i.e. flagship projects with appealing public spaces). This compromise and its political benefits also offer insights into why the opposition to public land sales has been virtually non-existent in France. Particularly if we compare it to the Italian case, privatisation and redevelopment appear to be politically legitimate issues. Challenges were limited and targeted specific aspects of the redevelopment project without snowballing into a general debate about the future of public land. 
However, it is quite clear that the viability of this compromise also relies on local government resources. Indeed, the costs of this privatisation have to a large extent been transferred to local governments who have been key investors in these redevelopment processes. This situation is unlikely to last. We have already described the decreasing transfers from central government. This situation could get worse as the government elected in 2017 plans to remove the council tax (taxe d'habitation), one of the main resources of municipalities (with expected compensation from central government). French bargained austerity is therefore likely to move closer to Italian gridlock austeritytype situations.

In the Italian case, local mitigation of public land austerity is limited. Here, the pressures inherent in public land privatizations have been accentuated by those austerity measures entailing a long-term reduction in financial transfers from central to local government. The intergovernmental system offers neither 'hand-holding' nor resources other than on an ad hoc basis. Public land transformation thus functions through a 'double' austerity where lack of intergovernmental mitigation combines with severe financial constraints imposed on local governments.

It is in this context that local expectations about redeveloping land to provide public facilities were highest and privatisation of public land was challenged the most. In Rome, Milan, Bolzano and Taranto, the local debate about the future of public land was - and still is - very heated, nurtured by groups that include academics, trade unions and neighbourhood, housing and other social movements, each favouring different forms of action (from public petitioning to squatting). They call for the redevelopment of public land as a response to the lack of public goods (i.e., affordable housing, cultural facilities, etc.). In Rome for instance, the citywide committee opposed to the private redevelopment of military barracks took the evocative name of 'Committee for the public use of barracks'. Unlike France, where this kind of argument is absent, they contest the very issue of public land privatisation and advocate common or public tenure and uses. 
This result raises questions concerning the politics of urban austerity. Indeed, routinized land privatization in France predetermines 'who gets what, when, and how' in the words of Laswell, and thus frames the political deal. In Italy however, decision-making uncertainties require more bargaining between public organisations and citizens while the lack of resources and redistributional measures in public land redevelopment make this bargaining more contentious and produce conflicts that further paralyse local adaptation to public land austerity policies. Interestingly, this situation has resulted in recent developments that promote other uses of Italian public real estate. On the one hand, 'selforganised' initiatives that promote generally temporary profit and non-profit activities (additional welfare amenities, co-working spaces, markets, artists' residences, labs, etc.) are flourishing (Patti and Polyak 2016). Again, these vary greatly from city to city, depending on both local social capital and support for local policies (Mangialardo and Micelli 2017). On the other hand, central government has recognised that part of public property can be used to support the production of local public goods. The agency in charge of managing public real estate has recently been implementing national programs of this type (e.g. 'Valore Paese Fari', 'Cammini e Percorsi') as well as specific projects, usually in third-tier cities and rural areas, while maintaining rent maximising strategies in larger cities.

\section{Conclusion}

This article contributes to an understanding of urban austerity by comparing public land disposal policies in France and Italy. For the past two decades, state reforms have recast not only management approaches, but the very idea of the public sector as landowner. However, empirically, there is a disparity between equivalent austeritarian-neoliberal reforms that cross national (French and Italian) and sectorial (army and rail) boundaries and the urban consequences of these policies. To make sense of this variation, our study focused on institutional and political variables as factors of differentiation, namely intergovernmental relations and local government capacity. The paper highlights the impact of institutional arrangements in the privatization of public land. Acknowledging that austerity is an encompassing policy paradigm for urban policies in European countries, but departing from the 'offloaded' conceptualization of intergovernmental 
relations employed in the literature on this topic, and not forgetting that local authorities may maintain resources and agency, the paper has offered and used a new analytical and comparative framework for making sense of urban austerity policies. Combining the variables of the intergovernmental system and local policy capacity provides four types that characterize local adaptations to austerity whether it is mitigated locally, nationally, both (i.e. opportunistically grasped by local governments) or neither of the two (i.e. gridlock austerity).

This model was developed to analyse public land austerity policies and therefore focuses on the field of land policy and related urban development arrangements. Consequently, it highlights the crucial role of both the resources provided by the intergovernmental system and local policy capacity in mitigating the effects of a state land austerity policy. If not supplemented by public investment, the policy of state land privatization is likely to produce unequal cities or gridlock redevelopment in cases of real estate market slack as observed in Italy.

More generally, the proposed model helps to analyse two different trajectories in 'mostsimilar' French and Italian cases, i.e. to demonstrate the role of the intergovernmental system and local planning capacity to shape urban austerity processes. In this sense, the comparative model is heuristic. For future research, we thus suggest that it could be used to compare urban austerity in other policy fields such as welfare, public utilities or sustainable development policies in cities.

\section{References}

Adisson F (2018) From state restructuring to urban restructuring: The intermediation of public landownership in urban development projects in France. European Urban and Regional Studies 25(4): 373-90.

Adisson F (2015) De l'aménagement du territoire au réaménagement des terrains de l'Etat. Politiques et projets de reconversion urbaine du domaine ferroviaire en France et en Italie. PhD Thesis, Politecnico di Milano and Université Paris-Est. 
Artioli F (2016) When Administrative Reforms Produce Territorial Differentiation. How Market-Oriented Policies Transform Military Brownfield Reconversion in France (1989-2012). Environment and Planning C: Government and Policy 34(8): 1759 $-75$.

Artioli F (2014) L'armée, les villes, l'État. Restructurations militaires et politiques urbaines: les transformations de l'intégration territoriale en France et en Italie. PhD Thesis, Science Po Paris.

Artioli F (2013) The Navy and the city: conflict, cooperation and political competition in the urban governance of Toulon. Urban Research \& Practice 6 (1): 75-94.

Besussi E (2013, August) Asset-Rich and Income-Poor. Emerging Mixed Modes of Urban Governance under Fiscal Crisis. Paper presented at the RC21 Conference, Berlin.

Blyth M (2013) Austerity: The history of a dangerous idea. New York: Oxford University Press.

Brunazzo M (2010) Italian Regionalism: A Semi-Federation is Taking Shape - Or is It?. In Baldersheim $\mathrm{H}$ and Rose EL (eds) Territorial Choice: The Politics of Boundaries and Borders. New York: Palgrave Macmillan, pp. 185-97.

Chorianopoulos I and Tselepi N (2017) Austerity urbanism: Rescaling and collaborative governance policies in Athens. European Urban and Regional Studies. DOI: 10.1177/096977641773330.

Christophers B (2017) The State and Financialization of Public Land in the United Kingdom. Antipode 49(1): 62-85.

Davies J and Blanco I (2017) Austerity urbanism: Patterns of neo-liberalisation and resistance in six cities of Spain and the UK. Environment and Planning A 49(7): 1517-36.

Della Porta D (2008) Comparative analysis: case-oriented versus variable-oriented research. In Della Porta D and Keating M (eds) Approaches and Methodologies in the Social Sciences: A Pluralist Perspective. Cambridge: Cambridge University Press, pp. 198-222. 
Directorate General for Regional and Urban Policy (1997) The EU Compendium of Spatial Planning Systems and Policies. Brussels: European Commission.

Eidelman G (2016) Rethinking Public Land Ownership and Urban Development: A Canadian Perspective. Cities 55: 122-26.

Gastaldi F and Camerin F (2017) Processi di dismissione degli immobili militari. Temi e problemi aperti per la rigenerazione urbana in Italia. Scienze Regionali 16(1): 10320.

Gerring J (2007) Case Study Research: Principles and Practices. Cambridge and New York: Cambridge University Press.

Goldsmith MJ and Page EC (2010) Changing Government Relations in Europe: From Localism to Intergovernmentalism. New York: Routledge.

Gray M and Barford A (2018) The Depths of the Cuts: the Uneven Geography of Local Government Austerity. Cambridge Journal of Regions Economy and Society 11(3): 541-63.

Haila A (2016) Urban Land Rent: Singapore as a Property State. Oxford: Wiley.

Haussermann H and Haila H (2004) The European City: A Conceptual Framework and Normative Project. In Kazepov Y (ed) Cities of Europe. Changing Contexts, Local Arrangements and the Challenge to Social Cohesion, Malden: Blackwell, 43-63. Hood C (1998) The Art of the State: Culture, Rhetoric, and Public Management. Oxford: Oxford University Press.

Hyötyläinen M and Haila A (2018) Entrepreneurial Public Real Estate Policy: The Case of Eiranranta, Helsinki. Geoforum 89: 137-44.

Kantor P, Savitch HV and Vicari Haddock S (1997) The Political Economy of Urban Regimes A Comparative Perspective. Urban Affairs Review 32(3): 348-77.

Keating M (2013) Rescaling the European State: The Making of Territory and the Rise of the Meso. Oxford: Oxford University Press.

Kivell PT and McKay I (1988) Public Ownership of Urban Land. Transactions of the Institute of British Geographers 13(2): 165-78.

Lobao LM and Adua L (2011) State Rescaling and Local Governments' Austerity Policies across the USA, 2001-2008. Cambridge Journal of Regions, Economy and Society 4(3): 419-35. 
Mangialardo A and Micelli E (2017) From Sources of Financial Value to Commons: Emerging Policies for Enhancing Public Real-Estate Assets in Italy. Papers in Regional Science. DOI: 10.1111/pirs.12310.

Meegan R, Kennett P, Jones G and Croft J (2014) Global Economic Crisis, Austerity and Neoliberal Urban Governance in England. Cambridge Journal of Regions, Economy and Society 7(1): 137-53.

Ministère de la Defense - Mission pour la Réalisation des Actifs Immobiliers (2006) Réussir la reconversion d'un site militaire ou industriel. Issy-les-Moulineaux: ESF.

Monastiriotis V (2011) Making Geographical Sense of the Greek Austerity Measures: Compositional Effects and Long-Run Implications. Cambridge Journal of Regions, Economy and Society 4(3): 323-37.

Patti D and Polyak L (2016) From Austerity to Self-Organization. The Changing Landscape of Social Services and Infrastructures in Rome. In Schönig B and Schipper S (eds) Urban Austerity. Impacts of the Global Financial Crisis on Cities in Europe. Berlin: Theater der Zeit, pp. 128-43.

Peck J (2012) Austerity Urbanism. American Cities under Extreme Economy. City 16(6): $626-55$.

Peck J and Whiteside H (2016) Financializing Detroit. Economic Geography 92(3): 23568.

Piganiol M (2017) Le prix du compromis politique. Revue française de sociologie 58(2): 267-93.

Pike A, Coombes M, O’Brien P and Tomaney J (2016) Austerity states, institutional dismantling and the governance of sub-national economic development: the demise of the regional development agencies in England. Territory, Politics, Governance 6(1): 118-44.

Pinson G (2009) Gouverner la ville par projet: urbanisme et gouvernance des villes européennes. Paris: Les Presses de Sciences Po.

Ritchie J, Lewis J and Elam G (2003) Designing and Selecting Samples. Qualitative Research Practice. London: SAGE Publications Ltd, pp. 77-108. 
Stoker G (1995) Regime Theory and Urban Politics. In Judge D, Stoker G and Wolman H (eds) Theories of Urban Politics. Thousand Oaks: SAGE, pp. 54-71.

Storper M (2016) The Neo-Liberal City as Idea and Reality. Territory, Politics, Governance 4(2): 241-63.

Streeck W (2014) The Politics of Public Debt: Neoliberalism, Capitalist Development and the Restructuring of the State. German Economic Review 15(1): 143-65.

Tarrow SG (1977) Between Center and Periphery. Grassroots Politicians in Italy and France. New Haven: Yale University Press.

Whiteside H (2017) The State's Estate: Devaluing and Revaluing 'Surplus' Public Land in Canada. Environment and Planning A. DOI: 0308518X17723631. 
Table 1. The case-studies

\begin{tabular}{|c|c|c|c|c|c|c|}
\hline Country & City & $\begin{array}{l}\text { Administrative } \\
\text { position within } \\
\text { the country }\end{array}$ & $\begin{array}{l}\text { Local } \\
\text { planning } \\
\text { capacity }\end{array}$ & $\begin{array}{l}\text { Economic } \\
\text { position within } \\
\text { the country }\end{array}$ & $\begin{array}{l}\text { Real estate } \\
\text { prices } \\
\text { (compared } \\
\text { to other } \\
\text { urban areas } \\
\text { in the } \\
\text { country) }\end{array}$ & $\begin{array}{l}\text { Real estate } \\
\text { prices } \\
\text { (€/sq.m for } \\
\text { residential, } \\
\text { June 2017) }\end{array}$ \\
\hline \multirow{4}{*}{$\begin{array}{c}\text { France } \\
\text { (redistributional } \\
\text { intergovernmental } \\
\text { system) }\end{array}$} & Paris & National capital & High & Global city & High & 8796 \\
\hline & Nantes & Regional capital & High & First-tier city & Medium & 2704 \\
\hline & Toulon & Provincial capital & Medium & Second-tier city & Medium & 2379 \\
\hline & Metz & Provincial capital & Medium & Second-tier city & Low & 1683 \\
\hline \multirow{5}{*}{$\begin{array}{c}\text { Italy } \\
\text { (offloading } \\
\text { intergovernmental } \\
\text { system) }\end{array}$} & Rome & National capital & Low & First-tier city & High & 3189 \\
\hline & Milan & Regional capital & Medium & Global city & High & 3236 \\
\hline & Bolzano & Provincial capital & High & Second-tier city & High & 3483 \\
\hline & Udine & Provincial capital & Medium & Second-tier city & Low & 1388 \\
\hline & Taranto & Provincial capital & Low & Second-tier city & Low & 1102 \\
\hline
\end{tabular}


Table 2. Sale and redevelopment of public assets in French and Italian cities

\begin{tabular}{lll}
$\begin{array}{l}\text { Sale and redevelopment } \\
\text { outputs }\end{array}$ & French cities & Italian cities \\
\hline Effectiveness of privatisation & $\begin{array}{l}\text { Large } \\
\text { More systematic sales and } \\
\text { redevelopments }\end{array}$ & $\begin{array}{l}\text { Limited } \\
\text { Limited number of } \\
\text { redeveloped assets, } \\
\text { privatisation failures }\end{array}$ \\
Procedures & $\begin{array}{l}\text { Homogeneous and pacified } \\
\text { "Routinized" procedures, } \\
\text { limited conflicts }\end{array}$ & $\begin{array}{l}\text { Variegated and conflictual } \\
\text { High variety of adopted } \\
\text { procedures, frequent } \\
\text { conflicts }\end{array}$ \\
& $\begin{array}{l}\text { More redistributional } \\
\text { Social housing and public } \\
\text { facilities }\end{array}$ & $\begin{array}{l}\text { Less redistributional } \\
\text { Rent maximization, socially } \\
\text { exclusive redevelopment }\end{array}$
\end{tabular}




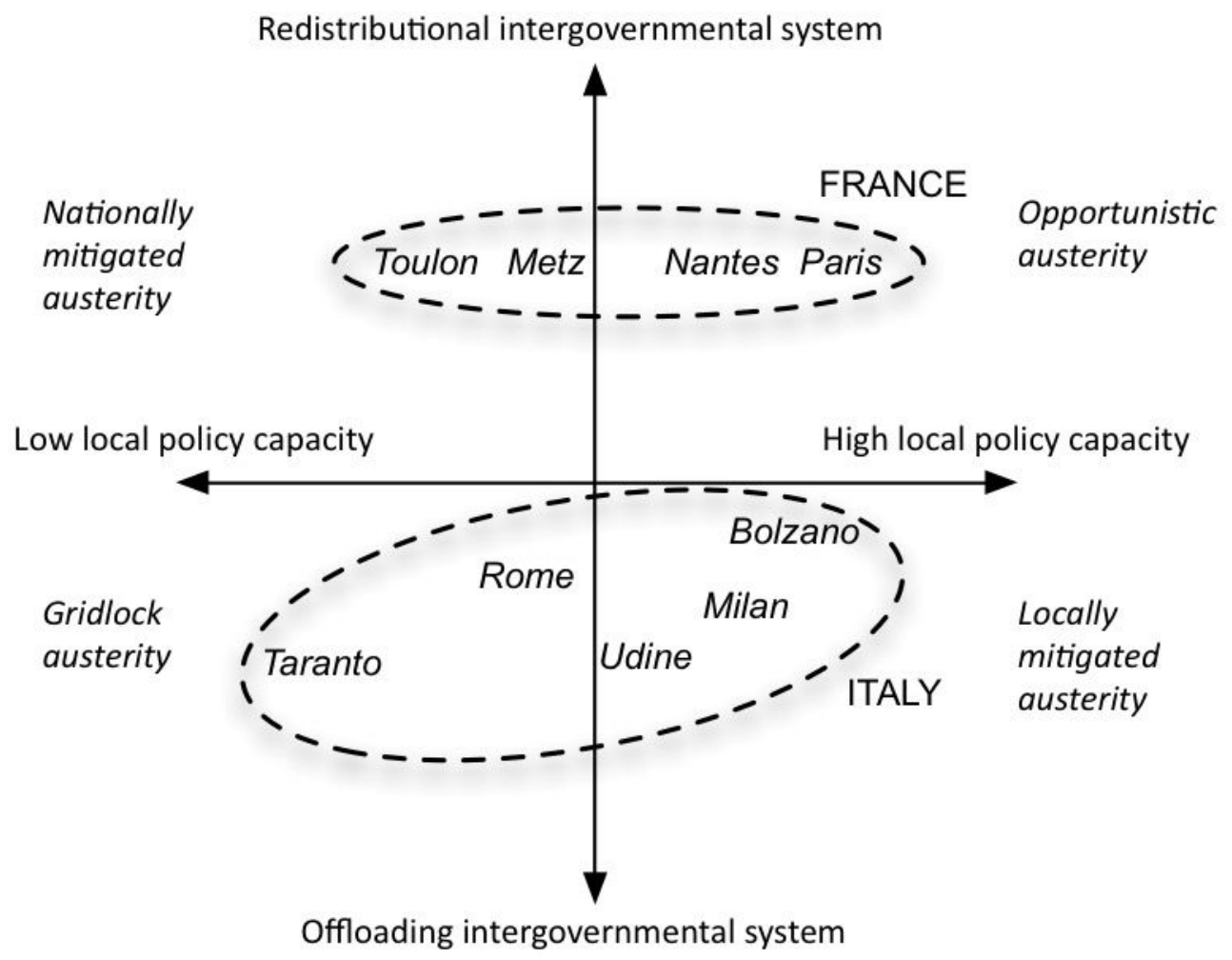

Figure 1 